Article

\title{
Re-Os Pyrite Geochronological Evidence of Three Mineralization Styles within the Jinchang Gold Deposit, Yanji-Dongning Metallogenic Belt, Northeast China
}

\author{
Shun-Da Li ${ }^{1}$, Zhi-Gao Wang ${ }^{2}$, Ke-Yong Wang ${ }^{1, *}$, Wen-Yan Cai ${ }^{1}$, Da-Wei Peng ${ }^{1}$, Li Xiao ${ }^{3}$ \\ and $\mathrm{Jie} \mathrm{Li}^{4}$ \\ 1 College of Earth Sciences, Jilin University, Changchun 130061, China; sdli16@mails.jlu.edu.cn (S.-D.L.); \\ wenyan_1025@126.com (W.-Y.C.); pdw308zy@163.com (D.-W.P.) \\ 2 College of Exploration and Surveying Engineering, Changchun Institute of Technology, \\ Changchun 130061, China; w458554302463@163.com \\ 3 Gold Geological Institute of CAPF, Langfang 065000, China; xiaoli1893@163.com \\ 4 State Key Laboratory of Isotope Geochemistry, Guangzhou Institute of Geochemistry, Chinese Academy of \\ Sciences, Guangzhou 510640, China; jieli@gig.ac.cn \\ * Correspondence: wangky@jlu.edu.cn; Tel.: +86-130-6900-4095
}

Received: 11 September 2018; Accepted: 1 October 2018; Published: 12 October 2018

\begin{abstract}
The Jinchang gold deposit is located in the eastern Yanji-Dongning Metallogenic Belt in Northeast China. The orebodies of the deposit are hosted within granite, diorite, and granodiorite, and are associated with gold-mineralized breccia pipes, disseminated gold in ores, and fault-controlled gold-bearing veins. Three paragenetic stages were identified: (1) early quartz-pyrite-arsenopyrite (stage 1); (2) quartz-pyrite-chalcopyrite (stage 2); and (3) late quartz-pyrite-galena-sphalerite (stage 3). Gold is hosted predominantly within pyrite. Pyrite separated from quartz-pyrite-arsenopyrite cement within the breccia-hosted ores $\left(\mathrm{Py}_{1}\right)$ yield a Re-Os isochron age of 102.9 $\pm 2.7 \mathrm{Ma}$ (MSWD = 0.17). Pyrite crystals from the quartz-pyrite-chalcopyrite veinlets $\left(\mathrm{Py}_{2}\right)$ yield a Re-Os isochron age of $102.0 \pm 3.4 \mathrm{Ma}\left(\mathrm{MSWD}=0.2\right.$ ). Pyrite separated from quartz-pyrite-galena-sphalerite veins $\left(\mathrm{Py}_{3}\right)$ yield a Re-Os isochron age of $100.9 \pm 3.1 \mathrm{Ma}$ (MSWD $=0.019$ ). Re-Os isotopic analyses of the three types of auriferous pyrite suggest that gold mineralization in the Jinchang Deposit occurred at 105.6-97.8 Ma (includes uncertainty). The initial ${ }^{187} \mathrm{Os} /{ }^{188} \mathrm{Os}$ values of the pyrites range between 0.04 and 0.60 , suggesting that Os in the pyrite crystals was derived from both crust and mantle sources.
\end{abstract}

Keywords: Re-Os isotopes; geochronology; Jinchang gold deposit; Yanji-Dongning Metallogenic Belt

\section{Introduction}

Studies investigating the genesis of hydrothermal gold deposits are commonly limited by a lack of suitable minerals to directly date the age of mineralization. The age of metallogenesis is commonly inferred from the timing of magmatism, deformation, metamorphism, and alteration; however, it is still difficult to determine the age of mineralization within a deposit that records evidence for multiple tectonic and magmatic events. Accurately dating the age of mineralization is crucial in determining the genesis and prospectivity of the deposit.

Recent advances in Re-Os isotopic systematics have seen an increase in the use of this technique to directly date the age of metal deposits. These developments have included improved capability to undertake Re-Os dating of molybdenite as well as more common minerals with lower Re and Os concentrations such as pyrite and arsenopyrite [1-3]. Many studies have undertaken Re-Os geochronology work on auriferous pyrites to date the age of gold deposits $[4,5]$. 
The Jinchang Deposit is a large gold deposit located in Heilongjiang Province, Northeast China. This deposit was discovered by the Chinese Armed Police Force in the 1990s. Exploration, which continues today, has involved 96,725 m of drilling of >200 holes, and $6339 \mathrm{~m}$ of underground tunnel development, revealing an estimated $80.4 \mathrm{t}$ gold resource with a grade of $8 \mathrm{~g} / \mathrm{t} \mathrm{Au}$.

Previous studies of the deposit have focused on its geological features, alteration, geochemistry, fluid inclusion systematics, and geochronology [6-9]. These studies have suggested that the Jinchang Deposit is a typical magmatic-hydrothermal deposit. The interpreted age of gold mineralization in the deposit is based on the $\mathrm{U}-\mathrm{Pb}, \mathrm{Rb}-\mathrm{Sr}$, and $\mathrm{Ar}-\mathrm{Ar}$ ages of host rocks and alteration minerals $[6,10,11]$. Ore formation is interpreted to have occurred between ca. 130 and $100 \mathrm{Ma}$, but the causative mechanism and timing of gold mineralization remain unclear within the context of the complex geological and magmatic evolution of the region.

We present Re-Os pyrite age data to constrain the timing of the various stages of mineralization within the Jinchang gold deposit. The results demonstrate that sulfide minerals can be used to determine the age of different types of mineralization, provide information on the origin of metals, and further our understanding of the genesis of the Jinchang gold deposit.

\section{Geological Background}

\subsection{Geological Setting}

Northeast China is located between the Siberian and North China cratons, and forms the eastern part of the Central Asian Orogenic Belt, which is the largest Phanerozoic accretionary orogen in the world [12]. Northeast China is subdivided by the Tayuan-Xiguitu, Nenjiang, and Mudanjing faults into, from east to west, the Erguna, Xinan, Songnen, and Jiamusi-Xingkai blocks (Figure 1A). The region records a prolonged geological evolution involving the emplacement of Archean-Paleoproterozoic rocks, mid-late Proterozoic rifting and subduction-collision related to the closure of the Paleo-Asian Ocean and Mesozoic subduction of the Pacific Plate and pervasive tectonomagmatic events [13,14].

The Yanji-Dongning area is located in the eastern part of Jilin and Heilongjiang provinces, within the Xingkai Block, which is bounded by the Dunhua-Mishan and Xar Moron-Changchun faults to the northwest and southeast, respectively (Figure 1B). The Yanji-Dongning area comprises Precambrian basement rocks that are overlain by Silurian-Quaternary sedimentary successions. The crystalline basement rocks were formed in high temperature and pressure environments and exposed to the surface due to the regional crustal uplift. These rocks comprise mica schists, granulites, and amphibolites. Silurian-Quaternary sedimentary successions are formed by subsequent weathering, erosion, sedimentation, and volcanic eruption. The Silurian metasedimentary rocks are overlain by Permian sandstones and greywackes, Triassic pyroclastic rocks, Jurassic intermediate-acidic pyroclastic volcanics, and Cretaceous siltstones, pelites, and tuffs. Unconsolidated Tertiary and Quaternary sediments cover the region. The main groups of faults trend NE-SW, NW-SE, and E-W. Intrusive rocks comprise Paleoproterozoic-Paleozoic granodiorites and Mesozoic granodiorites, monzogranites, and granites.

Gold mineralization occurs in the Yanji-Dongning area. The main deposits are the Nongping and Xiaoxinancha porphyry gold deposits, the mesothermal vein-hosted Naozhi Gold Deposit, and the epithermal vein-hosted Jiusangou, Wufeng-Wuxing, and Duhuangling gold deposits [15,16] (Figure 1B). 


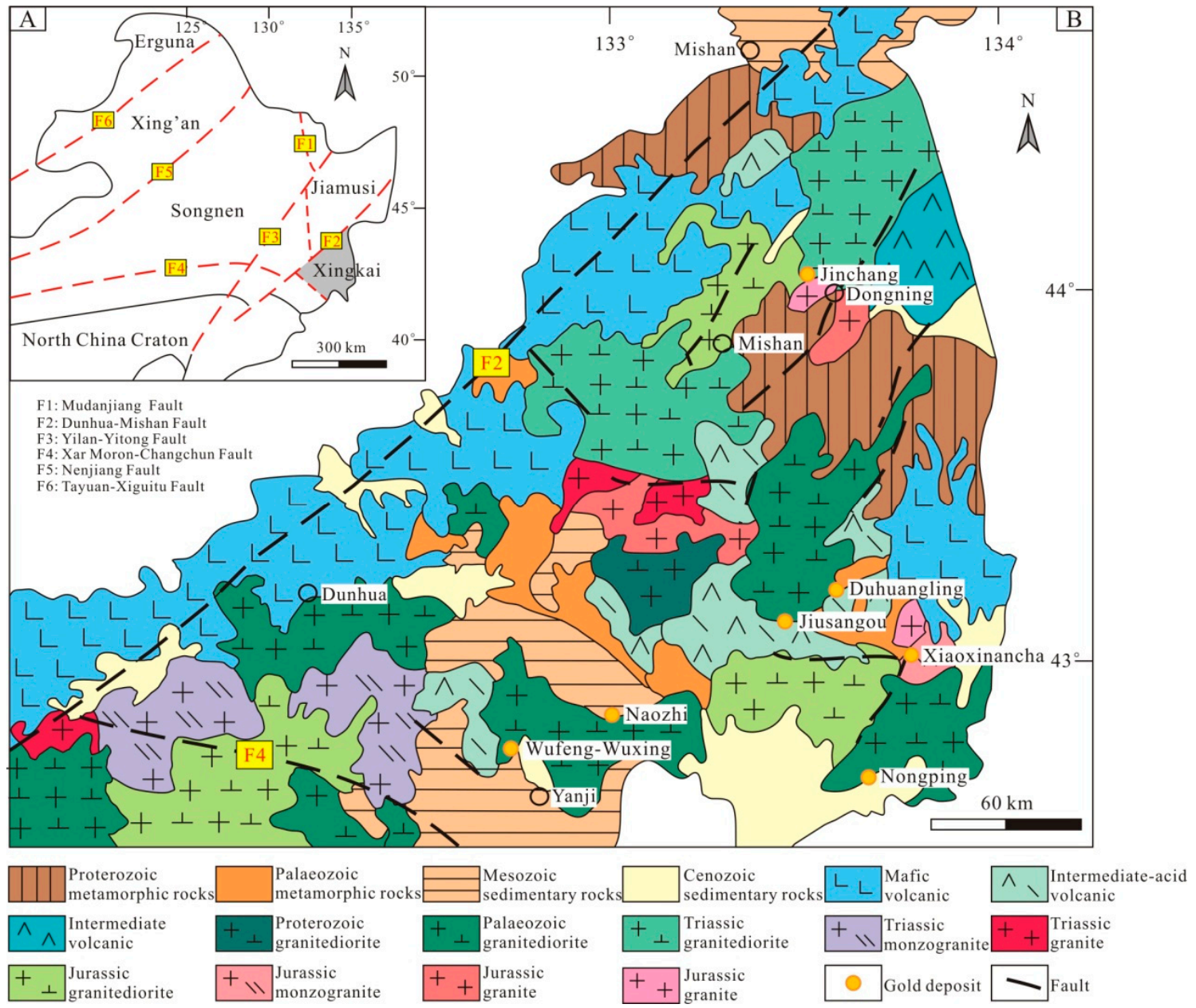

Figure 1. (A) Simplified tectonic map of Northeast China (modified after Wu et al. [17]). (B) Regional geological map of the Yanji-Dongning Metallogenic Belt, Northeast China (modified after Sun [18]), showing the location of the Jinchang gold deposit and other deposits discussed in this study.

\subsection{Jinchang Gold Deposit}

The Jinchang Deposit is located to the southeast of Jinchang Village (Figure 2). Outcrops are limited in this area, with exposures of andesitic-dacitic tuff restricted largely to the southeastern part of the mineralized area.

Crosscutting relationships suggest that the faults in this area can be classified into three groups with respect to the timing of mineralization. Early NE-SW, NW-SE, N-S, and E-W trending faults are widely distributed. Although they pre-date the mineralization, the intersections of these early faults facilitated fluid transport, leading to brecciation. Dome structures, and ring and radial faults in the central part of the ore field were contemporaneous with mineralization, with some orebodies occurring along these faults. Post-mineralization deformation was limited to the reactivation of early faults, which locally displaced the orebodies. 


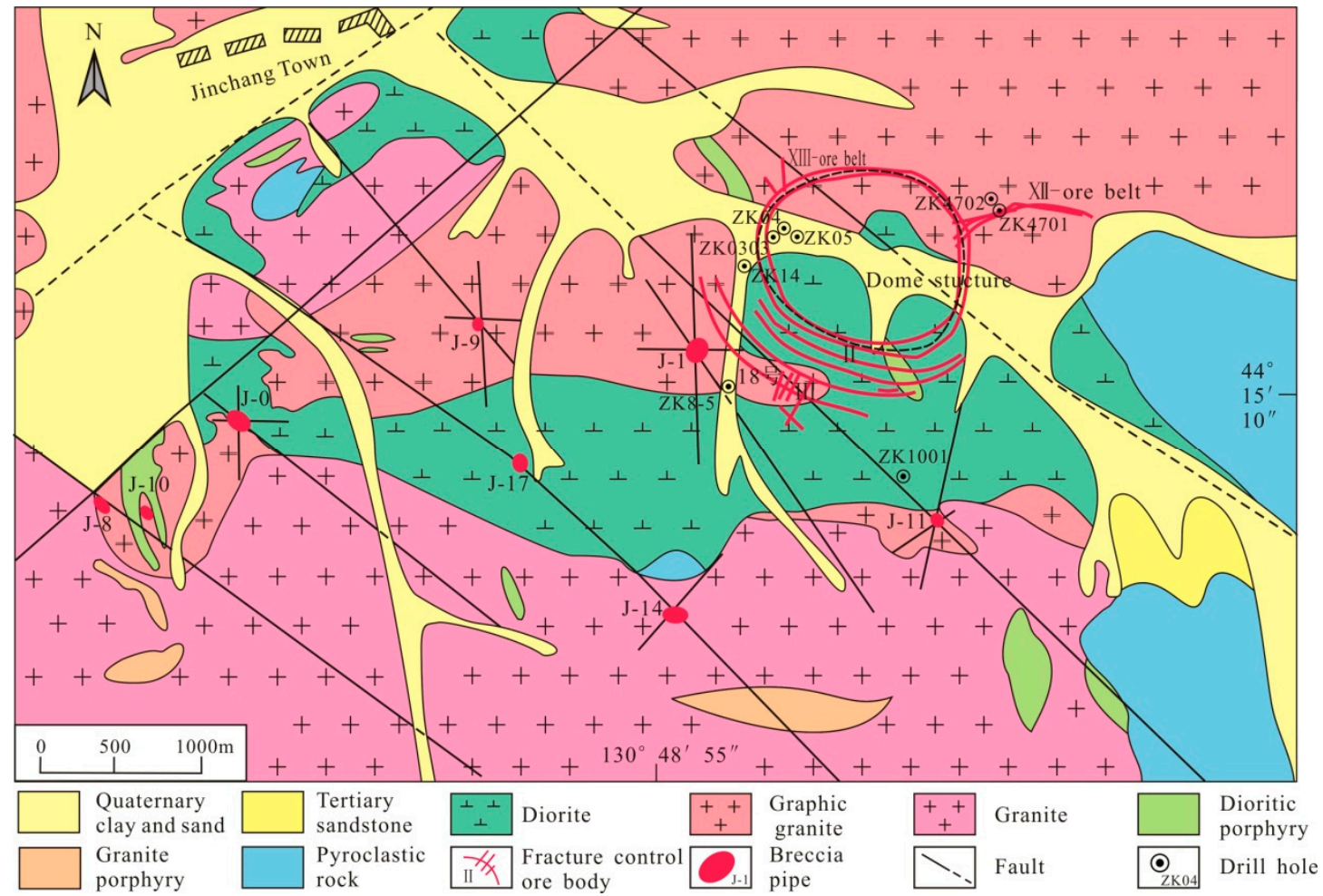

Figure 2. Geological map of the Jinchang gold deposit (modified after Zhang et al. [19]).

The variable characteristics of magmatic rocks within the ore field, their intrusive contact relationships, and age indicate a multi-stage emplacement history. The intrusive rocks comprise diorite, granite, graphic granite, granodiorite, and diorite and granite porphyries. The granitoids are calc-alkaline and high-K calc-alkaline with geochemical affinities to typical island-arc intrusive rocks [20,21]. The diorites and diorite porphyries are calc-alkaline and have geochemical affinities to adakites [20].

Diorite, graphic granite, and granite are widely exposed within the Jinchang Deposit and yield $\mathrm{U}-\mathrm{Pb}$ ages of 209-185 Ma, indicating that they were emplaced after collision of the North China Craton and the Jiamusi-Xingkai Block $[19,20,22,23]$. These rocks are the main hosts of the ore body and are extensively altered adjacent to the mineralization. The granodiorite, diorite porphyry, and granite porphyry yield $\mathrm{U}-\mathrm{Pb}$ ages of 118-106 Ma, indicating that these rocks were emplaced during subduction of the Pacific Plate beneath the Eurasian Plate [19-21,23,24]. Several diorite porphyry and granite porphyry dikes are crosscut by the ore body and are therefore interpreted to have formed prior to mineralization. Granodiorite is widespread, was emplaced in the deepest parts of the area (J11, J14, J17, and No. 18 orebodies), is extensively altered, and contains disseminated pyrite, suggesting a causal link between granodiorite emplacement and mineralization.

\section{Mineralization}

Exploration of the Jinchang Deposit prior to 2017 resulted in the discovery of 23 orebodies and three mineralization types (i.e., breccia pipes, disseminated veinlets, and fault-controlled veins).

\subsection{Breccia Pipe Mineralization}

Breccia pipe mineralization is the dominant source of gold within the deposit, accounting for $>41 \%$ of the total resources in the ore field. Eight large breccia pipes are presently documented (J-0, $\mathrm{J}-1, \mathrm{~J}-8, \mathrm{~J}-9, \mathrm{~J}-10, \mathrm{~J}-11, \mathrm{~J}-14$, and J-17), extending in a rough line from east to west, controlled by a major NW-SE-striking fault (Figure 2). The largest breccia pipe (J-1) is located at the intersection of N-S, NW-SE, and E-W striking faults, and occurs primarily within graphic granite. J-1 is pipe-like in form, with 5-15 $\mathrm{m}$ of diorite occurring above the orebody. Dikes comprising diorite porphyries 
occur at a deeper structural level (Figure 3A). The orebody is $46 \mathrm{~m}$ long and $30 \mathrm{~m}$ wide at the surface, with an average thickness of $21 \mathrm{~m}$ and an average grade of $8.1 \mathrm{~g} / \mathrm{t} \mathrm{Au}$. It plunges $80^{\circ}-82^{\circ}$ toward $155^{\circ}-160^{\circ}$ to a depth of $540 \mathrm{~m}$. The ore rock comprises primarily cement and breccia (Figure $\left.4 \mathrm{~A}-\mathrm{D}\right)$, the latter constituting up to $50 \%-80 \%$ of the total rock by volume. The breccia consists of clasts of diorite, granite, and diorite and granite porphyries that are lenticular or angular in shape and 10-25 cm in size. The breccias are cemented mainly by sulfides (i.e., pyrite, arsenopyrite, and chalcopyrite) and alteration minerals (i.e., feldspar, sericite, and quartz). Pyrite alteration is extensive in the cement, but is not observed within the breccias.

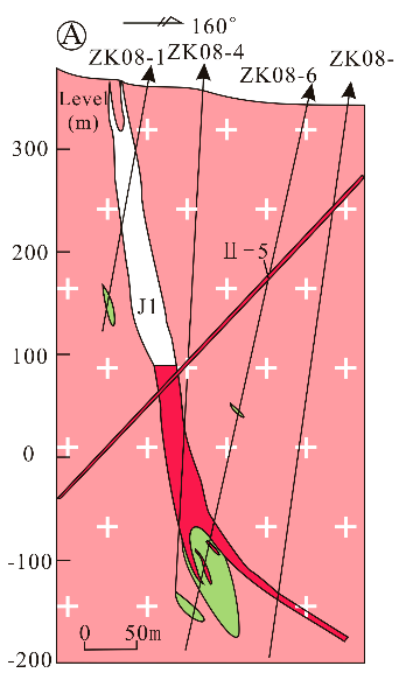

(D)
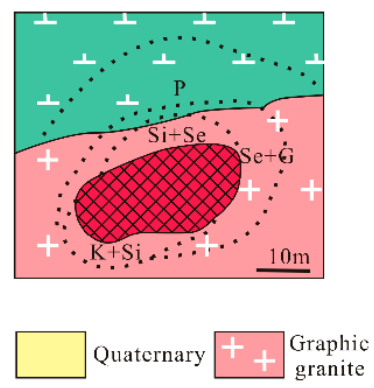

P Propylitic

Se Scricitization

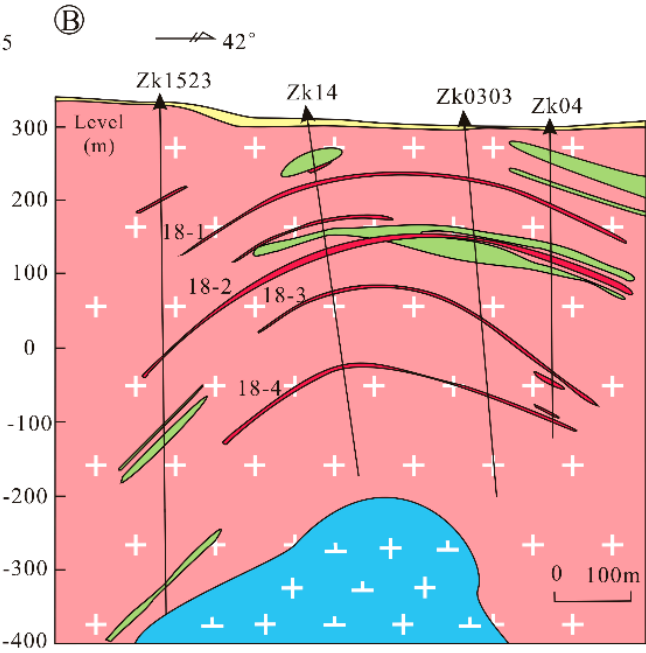

().
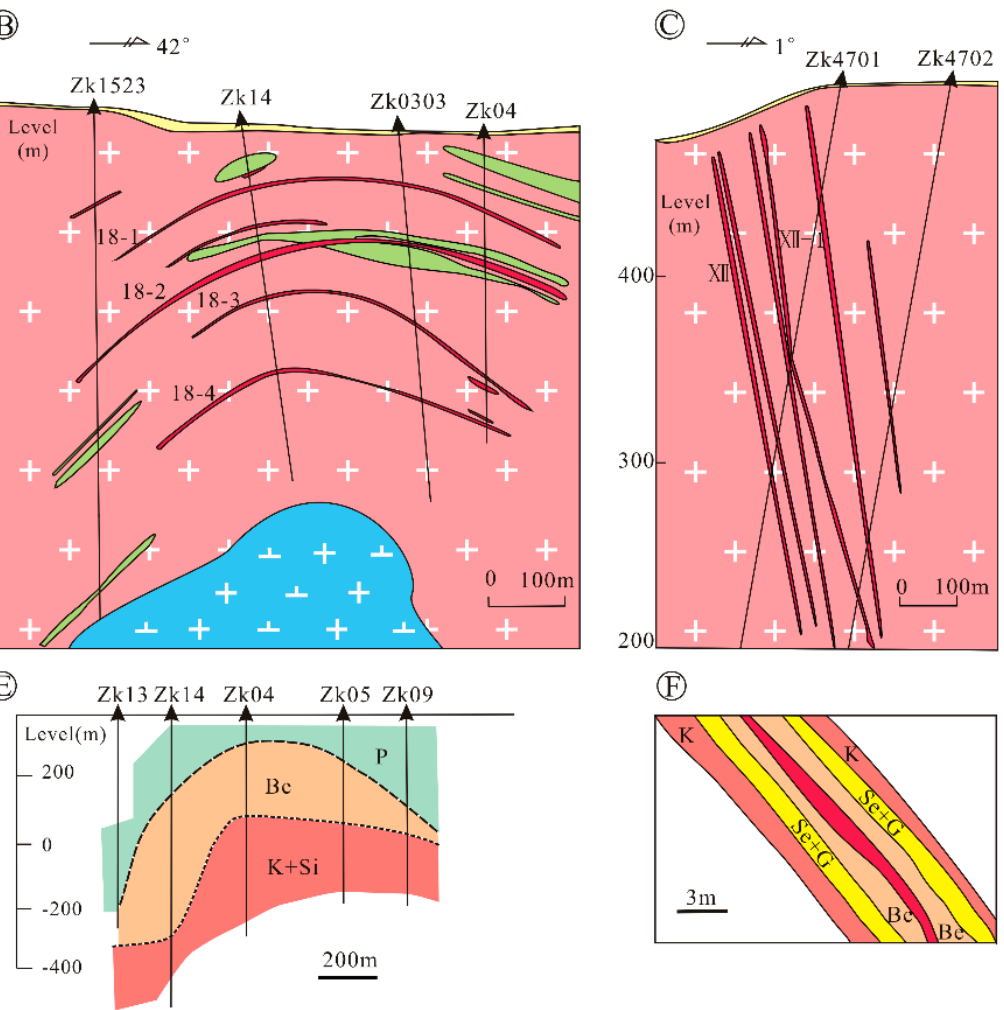

(E)

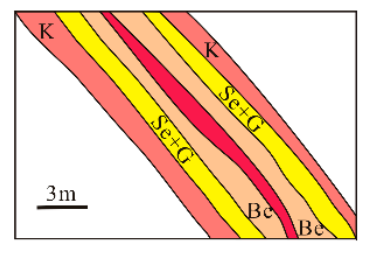

Figure 3. Geological sections and alteration patterns of the ore bodies (modified after Zhang et al. [19]); (A) geological cross-section of the J-1 ore body; (B) geological cross-section of the No. 18 ore body; (C) geological cross-section of the XII ore body; (D) alteration patterns of the J-1 ore body; (E) alteration patterns of the No. 18 ore body; (F) alteration patterns of the XII ore body.

Alteration of the wall rock is variable external to the mineralized pipe (Figure 3D). K-feldspar alteration, silicification, and sericitization are observed adjacent to the mineralized breccia pipe, whereas sericite-kaolinite and propylitic alteration occurs farther from the mineralized domain, in the outermost part of the northern breccia pipe [25]. 

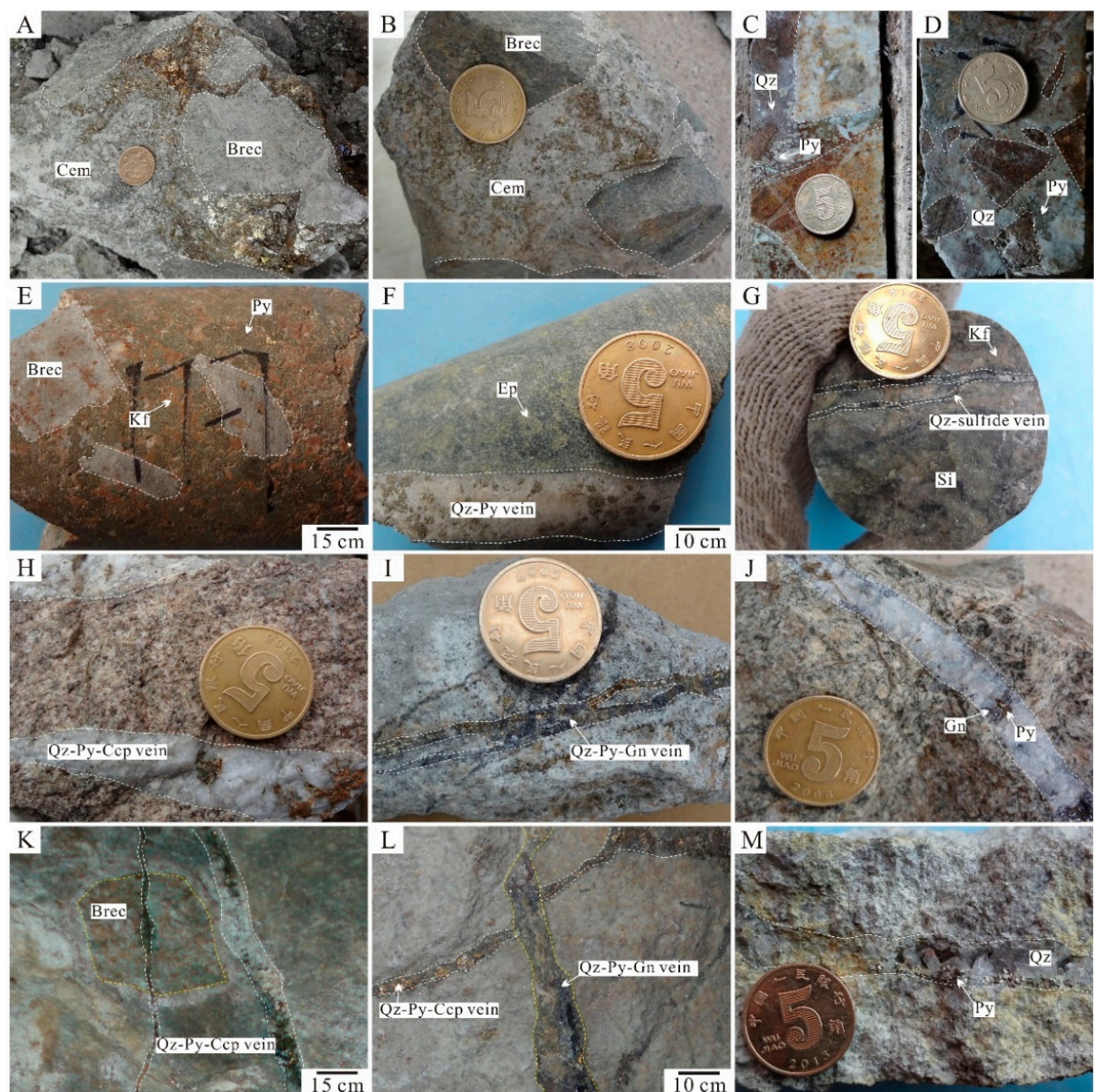

Figure 4. Photographs of ore from the Jinchang gold deposit. (A-D) Breccia-hosted ore; (E) K-feldspar alteration in the cement of the breccia-hosted ore; $(\mathbf{F})$ epidote alteration of the wall-rock surrounding a quartz-pyrite vein; (G) silicification of the wall-rock surrounding a quartz-sulfide veinlet; (H) quartzpyrite-chalcopyrite vein; (I,J) quartz-pyrite-galena veins; (K) breccia-hosted ore crosscut by a quartzpyrite-chalcopyrite vein; (L) quartz-pyrite-chalcopyrite vein crosscut by a quartz-pyrite-galena vein; (M) drusy structure in the ore. Abbreviations: Cem, cement; Brec, breccia; Qz, quartz; Ep, epidote; Kf, K-feldspar; Si, silicification; Py, pyrite; Ccp, chalcopyrite; Gn, galena; Sp, sphalerite.

\subsection{Veinlet Disseminated Mineralization}

The No. 18 orebody is a typical example of veinlet disseminated mineralization, accounting for $\sim 20 \%$ of the total resources in the ore field. The orebody is hosted within graphic granite and several diorite porphyry dikes beneath a dome structure. The orebody appears to be layered and is divided into four sub-bodies that are labeled 18-1 to 18-4, from top to bottom (Figure 3B). These sub-bodies are $0.6-7.9 \mathrm{~m}$ thick, $\sim 800 \mathrm{~m}$ long, and have an average grade of $11.23 \mathrm{~g} / \mathrm{t}$ Au. They strike toward $138^{\circ}$, $\operatorname{dip} \sim 47^{\circ}$ to the SW, and extend to depths of 160-490 m. Drill holes have intersected granodiorite at depth. The ore minerals are mainly pyrite and chalcopyrite, and lesser molybdenite, chalcocite, bornite, azurite, sphalerite, galena, and gold. Quartz is the main gangue mineral, with minor sericite, chlorite, and epidote.

The wall rock and concealed granodiorite observed in the drill holes are both altered. From depth to the surface, the alteration varies from K-feldspar alteration and silicification to beresitization and finally propylitic alteration [25] (Figure 3D).

\subsection{Fault-Controlled Vein Mineralization}

Fault-controlled vein mineralization accounts for 39\% of the total Au resources in the ore field, including within ore belts II, III, and XII. Vein development was controlled primarily by ring and radial 
faults associated with a dome. The forming of the dome is resulted from intrusion of magma. Ore belt $\mathrm{XII}$ is typical of this type of mineralization, as it comprises a swarm of veins within graphic granite that are controlled by E-W-trending radial faults in the northeastern part of the lava dome (Figure 2). This ore belt is $460 \mathrm{~m}$ long, $0.2-1.78 \mathrm{~m}$ thick, and has an average grade of $9.34 \mathrm{~g} / \mathrm{t} \mathrm{Au}$. The orebodies plunge $70^{\circ}-80^{\circ}$ toward $001^{\circ}-005^{\circ}$ and extend to depths of $190-510 \mathrm{~m}$. The ore minerals include pyrite, sphalerite, galena, and minor chalcopyrite. The gangue minerals are predominantly quartz and minor carbonate (Figure 4H).

Wall rock alteration occurs over several meters from the fault-controlled veins, is symmetrical about the veins, and is more extensive than alteration associated with the other mineralization styles (Figure 3F). With increasing distance from the ore body, the wall rock is affected by quartz-sericite, sericite-kaolinite, and subsequently K-feldspar alteration, although the boundaries between these domains are gradational [25].

The Jinchang Deposit comprises a number of hydrothermal veins and mineral assemblages. The mineral assemblages and their crosscutting relationships indicate three mineralization stages (Figures 4-6). Stage 1 mineralization occurred primarily within the cement of the breccia-hosted ore. This was the most important ore-forming stage as it involved the deposition of abundant native gold (Figure 5A). Stage 1 mineralization is also characterized by milky white quartz, pyrite, and lesser arsenopyrite, K-feldspar, and sericite (Figure 4A-D). Pyrite is the most abundant ore mineral, commonly occurring within the cement as coarse-grained pentagonal dodecahedra and tetragonal trisoctahedra crystals (Figure 4A,B), and locally as fine- to medium-grained aggregates (Figure 4C).
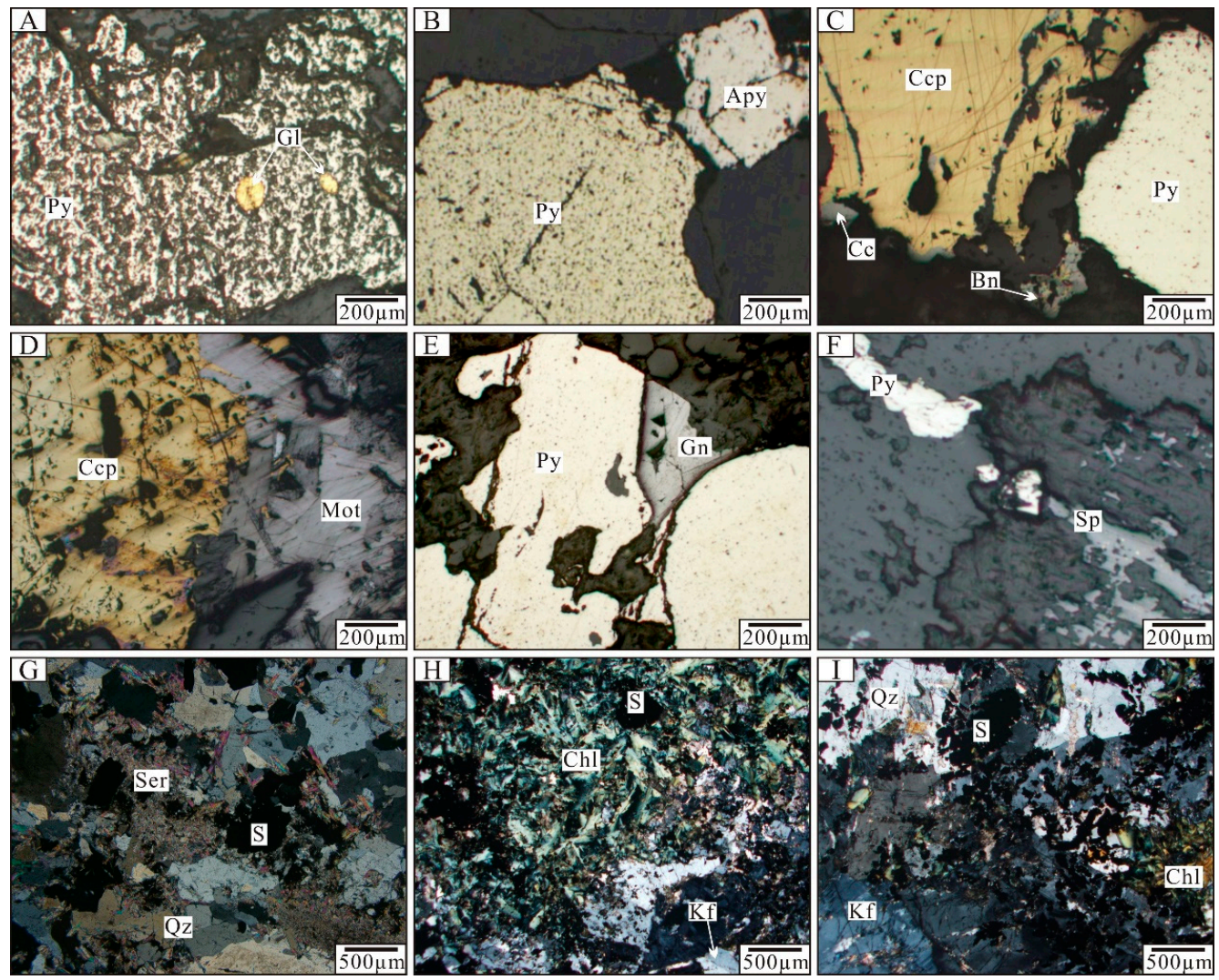

Figure 5. Photomicrographs of key mineral assemblages in the Jinchang Deposit. (A) Native gold in pyrite; (B) coexisting pyrite and arsenopyrite; (C) pyrite-chalcopyrite-chalcocite-bornite assemblage; (D) chalcopyrite-molybdenite assemblage; (E) coexisting pyrite and galena; (F) pyrite-sphalerite veinlet; $(\mathbf{G})$ beresitization of the wall-rock; $(\mathbf{H}, \mathbf{I})$ chloritization and K-feldspar alteration of wall-rock. Abbreviations: Qz, quartz; Ser, sericite; Chl, chlorite; Kf, K-feldspar; S, sulfide; Py, pyrite; Ccp, chalcopyrite; Gn, galena; Sp, sphalerite; Apy, arsenopyrite; Mot, molybdenite; Bn, bornite; Cc, chalcocite. 


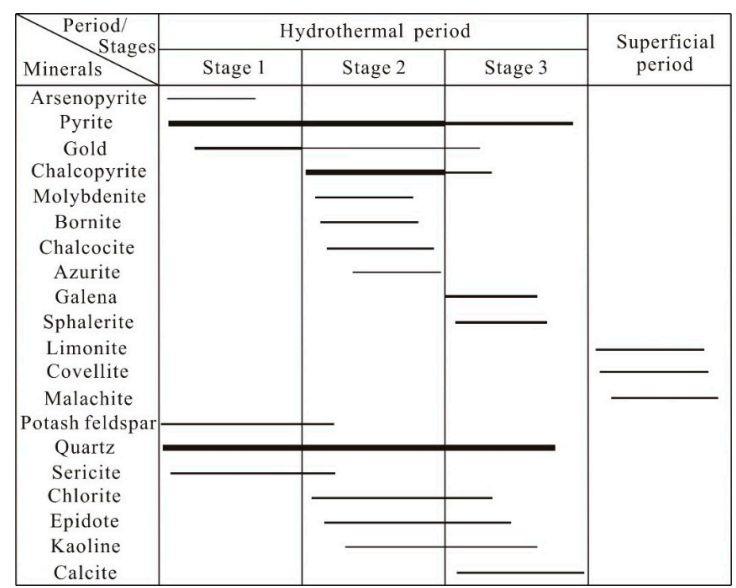

Figure 6. Mineral paragenesis for the Jinchang gold deposit.

Stage 2 mineralization involved the formation of economic quartz-pyrite-chalcopyrite veins and widespread in veinlet disseminated ores (Figure $4 \mathrm{H}$ ). These veins also comprise small amounts of molybdenite, chalcocite, bornite, azurite, gold, chlorite, and epidote. Chalcopyrite is the dominant sulfide and occurs as anhedral crystals intergrown with pyrite in quartz veins (Figure 5C). Molybdenite is rare, typically exhibits a hexagonal shape, and occurs as aggregates that are intergrown with chalcopyrite (Figure 5D). The breccia-hosted ore is crosscut by the quartz-pyrite-chalcopyrite veins and is observed in the tunnel at the $30 \mathrm{~m}$ level (Figure $4 \mathrm{~K}$ ).

Stage 3 mineralization involved the formation of quartz-pyrite-galena-sphalerite veins (Figure 4I,J) that also contain minor gold, chlorite, epidote, kaolinite, and calcite. Pyrite commonly occurs as hypidiomorphic or xenomorphic crystals that are intergrown with galena and sphalerite in quartz veinlets (Figure 5E,F). These veins have a limited distribution and commonly cut across quartz-pyrite-chalcopyrite veins, suggesting that they formed relatively late (Figure $4 \mathrm{~L}$ ). These veins are associated with fault-controlled vein mineralization and are not observed in the breccia.

\section{Sample Selection and Analytical Methods}

Fifteen samples of auriferous pyrite were collected from five drill holes (ZKE01, ZK05, ZK11, ZK14, and ZK4702) and underground tunnels for Re-Os analysis (Table 1). Re-Os isotopic analyses were undertaken on pyrites from the cement of breccia-hosted ore $\left(\mathrm{Py}_{1}\right)$, within quartz-pyrite-chalcopyrite veins $\left(\mathrm{Py}_{2}\right)$, and within quartz-pyrite-galena-sphalerite veins $\left(\mathrm{Py}_{3}\right)$. These three types of pyrite are representative of the observed breccia pipe, veinlet disseminated, and fault-controlled vein mineralization styles, respectively. Samples that displayed late-stage sulfide replacement were not analyzed to avoid the influence of late-stage hydrothermal alteration on the results.

We employed the Carius tube digestion technique commonly used in our lab for Re-Os chemistry [26]. About $0.5-2 \mathrm{~g}$ of each powdered sample was digested and equilibrated with ${ }^{185} \mathrm{Re}$ - and ${ }^{190} \mathrm{Os}$-enriched spikes in reverse aqua regia $\left(7.5 \mathrm{~mL}\right.$ concentrated $\mathrm{HNO}_{3}+2.5 \mathrm{~mL}$ concentrated $\left.\mathrm{HCl}\right)$ for $24 \mathrm{~h}$ at $240{ }^{\circ} \mathrm{C}$ in sealed Carius tubes. Osmium was extracted by solvent extraction into $\mathrm{CCl}_{4}$ and back-extraction into concentrated $\mathrm{HBr}[27,28]$, with subsequent cleanup by microdistillation [29]. The Re fraction was separated and purified using anion column chromatography.

Mass spectrometry procedures for the Os are given in Li et al. [30]. Os was loaded onto Pt filaments and measured as $\mathrm{OsO}_{3}{ }^{-}$ions by negative-thermal ionization mass spectrometry (N-TIMS) using the electron multiplier mode on a Thermo-Finnigan Triton [31,32] at the State Key Laboratory of Isotope Geochemistry, Guangzhou Institute of Geochemistry, Chinese Academy of Sciences, Guangzhou, China. Repeated analyses of the Os standard solution (Merck Chemical AA standard solution) yield a mean ${ }^{187} \mathrm{Os} /{ }^{188} \mathrm{Os}$ value of $0.12052 \pm 0.00032(2 \mathrm{SD}, n=5)$ for the period of analysis. These values are in good agreement with a value of $0.12022 \pm 0.00020(2 \mathrm{SD}, n=14)$ measured on the same mass spectrometer in Faraday cup mode [33]. 
Table 1. Re-Os isotopic data for auriferous pyrites from various locations in the Jinchang gold deposit.

\begin{tabular}{|c|c|c|c|c|c|c|c|c|c|c|c|}
\hline Pyrite & Sample & Location & $\begin{array}{c}\operatorname{Re} \\
\text { Conc (ppt) }\end{array}$ & 2SE & $\begin{array}{c}\text { Os } \\
\text { Conc (ppt) }\end{array}$ & 2SE & ${ }^{187} \mathrm{Os} /{ }^{188} \mathrm{Os}$ & $2 \sigma$ & ${ }^{187} \mathrm{Re} /{ }^{188} \mathrm{Os}$ & 2SE & $\begin{array}{c}\text { Initial } \\
{ }^{187} \mathrm{Os} /{ }^{188} \mathrm{Os}\end{array}$ \\
\hline \multirow{5}{*}{$\mathrm{Py}_{1}$} & J1-1 & ZKE01 at $84 \mathrm{~m}$ level & 9906 & 268.75 & 11.50 & 0.21 & 70.72 & 0.79 & 42,853 & 1408.28 & -2.80 \\
\hline & $\mathrm{J} 1-2$ & ZKE01 at $64 \mathrm{~m}$ level & 9643 & 147.37 & 11.78 & 0.21 & 52.22 & 0.47 & 31,501 & 740.43 & -1.82 \\
\hline & $\mathrm{J} 1-3$ & $30 \mathrm{~m}$ level middle section & 10,475 & 159.15 & 14.61 & 0.36 & 16.48 & 0.40 & 10,855 & 314.64 & -2.14 \\
\hline & $\mathrm{J} 1-4$ & $30 \mathrm{~m}$ level middle section & 9908 & 104.95 & 11.82 & 0.37 & 68.68 & 0.93 & 41,376 & 1354.88 & -2.31 \\
\hline & $\mathrm{J} 1-5$ & $30 \mathrm{~m}$ level middle section & 9856 & 121.56 & 11.66 & 0.24 & 58.53 & 0.71 & 35,295 & 1024.55 & -2.02 \\
\hline \multirow{5}{*}{$\mathrm{Py}_{2}$} & $\mathrm{~J} 18-1$ & ZK05 at $280 \mathrm{~m}$ level & 4194 & 76.99 & 5.09 & 0.09 & 50.28 & 0.38 & 31,074 & 804.77 & -2.57 \\
\hline & $\mathrm{J} 18-2$ & ZK05 at $362 \mathrm{~m}$ level & 4087 & 61.62 & 6.12 & 0.05 & 19.04 & 0.16 & 11,203 & 196.09 & -0.01 \\
\hline & J18-3 & ZK11 at $235 \mathrm{~m}$ level & 4224 & 153.08 & 6.20 & 0.05 & 21.30 & 0.17 & 12,395 & 460.54 & 0.22 \\
\hline & J18-4 & ZK11 at $342 \mathrm{~m}$ level & 4541 & 96.97 & 5.95 & 0.05 & 36.70 & 0.23 & 21,496 & 498.65 & 0.14 \\
\hline & $\mathrm{J} 18-5$ & ZK14 at $166 \mathrm{~m}$ level & 4125 & 73.58 & 5.55 & 0.05 & 52.36 & 0.43 & 30,856 & 706.91 & -0.12 \\
\hline \multirow{5}{*}{$\mathrm{Py}_{3}$} & Jh-1 & $374 \mathrm{~m}$ level middle section & 1437 & 26.20 & 3.12 & 0.05 & 7.36 & 0.10 & 4054 & 96.79 & 0.54 \\
\hline & Jh-2 & $374 \mathrm{~m}$ level middle section & 1255 & 36.95 & 2.94 & 0.02 & 7.19 & 0.08 & 3957 & 119.94 & 0.53 \\
\hline & Jh-3 & $374 \mathrm{~m}$ level middle section & 1346 & 20.85 & 3.57 & 0.02 & 6.47 & 0.05 & 3527 & 56.64 & 0.53 \\
\hline & Jh-4 & ZK4702 at $186 \mathrm{~m}$ level & 1735 & 13.05 & 3.21 & 0.03 & 11.39 & 0.13 & 6443 & 76.36 & 0.55 \\
\hline & Jh-5 & ZK4702 at $287 \mathrm{~m}$ level & 1185 & 20.46 & 3.02 & 0.02 & 11.21 & 0.06 & 6354 & 83.55 & 0.52 \\
\hline
\end{tabular}


Rhenium mass fraction was analyzed by inductively coupled plasma mass spectrometry (Thermo Elemental X2 Series). A conventional low volume quartz impact bead spray chamber with a Peltier cooled $\left(3^{\circ} \mathrm{C}\right)$ and a $0.4 \mathrm{~mL} \cdot \mathrm{min}^{-1}$ borosilicate nebulizer (MicroMist GE) was used in the determinations. Ion lens settings, nebulizer gas flow rate and torch position were optimized daily using a $10 \mathrm{ng} \cdot \mathrm{mL}^{-1}$ tuning In-Ce mixture standard solution in order to obtain the high instrumental sensitivity and low oxide production levels. A peristaltic pump was not used, as free aspiration of the nebulizer provided better signal stability. The details of measurements are described elsewhere [34].

Total procedural blanks (TPBs) were $0.72 \pm 0.44 \mathrm{pg}(1 \mathrm{SE}, n=2)$ with an ${ }^{187} \mathrm{Os} /{ }^{188}$ Os ratio of $0.67 \pm 0.55$ (1SE, $n=2)$ on average for Os and $4.0 \pm 0.1 \mathrm{pg}(1 \mathrm{SE}, n=2)$ for Re. All data were corrected for the procedural blank for each analytical batch. Blank contributions for mafic-ultrmafic rock samples were generally insignificant. The average values $\left({ }^{187} \mathrm{Os} /{ }^{188} \mathrm{Os}=0.13369 \pm 0.00014\right.$, Os $=0.340 \pm 0.032 \mathrm{ppb}, \operatorname{Re}=0.691 \pm 0.002 \mathrm{ppb}, 1 \mathrm{SE}, n=2)$ are in good agreement with published data for basaltic reference material BIR-1 [35-37].

Errors for Re and Os concentration and ${ }^{187} \mathrm{Re} /{ }^{188} \mathrm{Os}$ and ${ }^{187} \mathrm{Os} /{ }^{188} \mathrm{Os}$ isotopic ratios were determined by numerical error propagation and include spike calibration uncertainties an in-run precision during mass-spectrometry measurements for both Re and Os.

\section{Results}

The blank-corrected Re and Os data for 15 pyrite samples from the Jinchang Deposit are provided in Table 1. Isochrons for these samples were calculated using ISOPLOT software [38] and employing a ${ }^{187}$ Re decay constant of $1.666 \times 10^{-11}$ year $^{-1}$ [39].

Total Re and Os concentrations in $\mathrm{Py}_{1}$ range between 9643 and 10,475, and 11.50 and 14.61 ppt, respectively, corresponding to ${ }^{187} \mathrm{Re} /{ }^{188}$ Os ratios between 10,855 and 42,853 , and ${ }^{187}$ Os $/{ }^{188}$ Os ratios of 16.48-70.72. Py1 yielded an individual model 3 Re-Os isochron age of 102.9 $\pm 2.7 \mathrm{Ma}$ (2SE (Standard error); mean square weighted deviation $(\mathrm{MSWD})=0.17$; initial ${ }^{187} \mathrm{Os} /{ }^{188} \mathrm{Os}\left(\mathrm{I}_{\mathrm{Os}}\right)=-2.1 \pm 1.0$; Figure $\left.7 \mathrm{~A}\right)$.
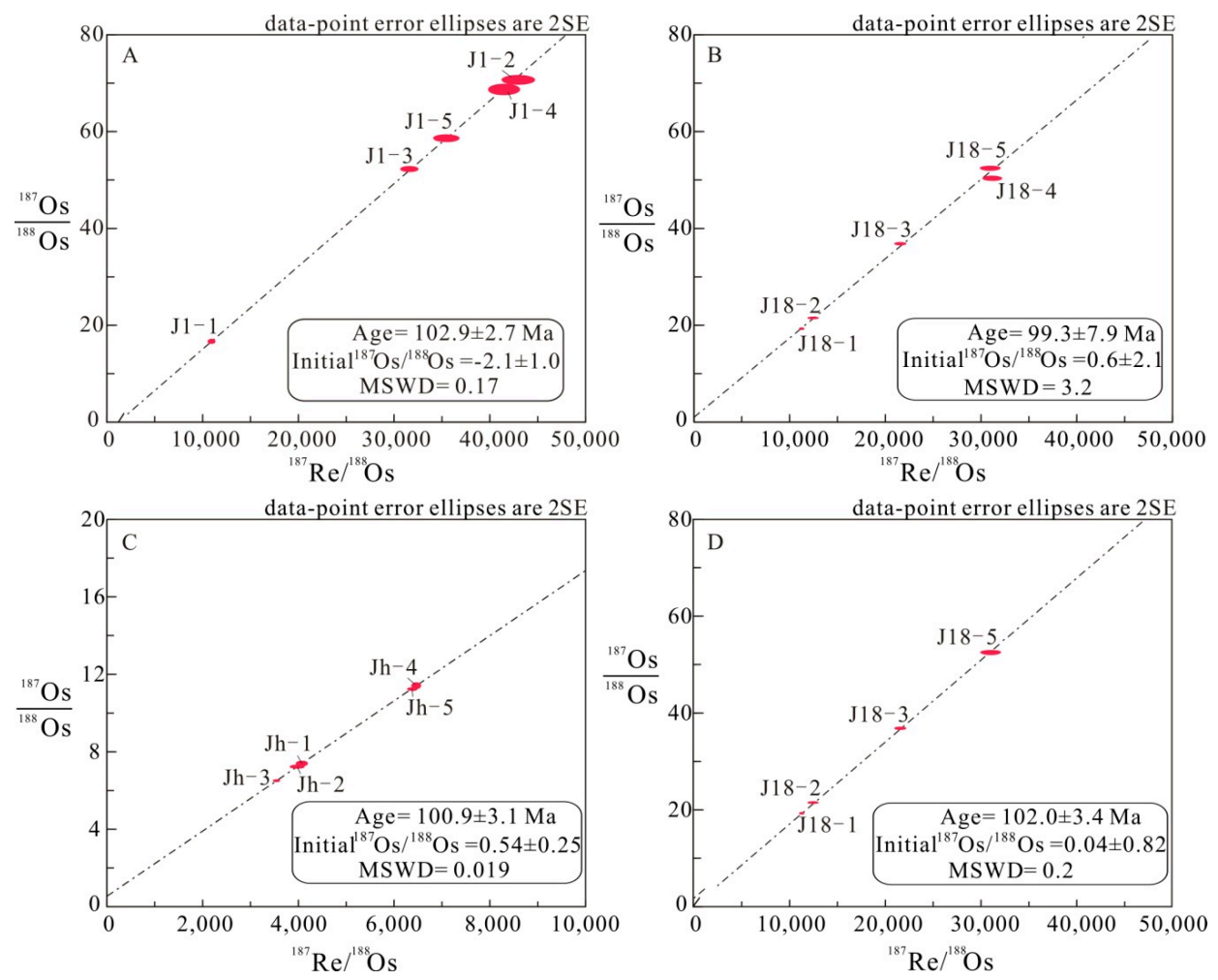

Figure 7. Re-Os isochron plots of stage 1-3 pyrites from the Jinchang Gold Deposit. (A) Isochron age of five analyses of $\mathrm{Py}_{1} ;(\mathbf{B})$ isochron age of five analyses of $\mathrm{Py}_{2} ;(\mathbf{C})$ isochron age of five analyses of $\mathrm{Py}_{3}$; (D) isochron age of four analyses (excluding J18-4) of $\mathrm{Py}_{2}$. 
Rhenium (Re) and Osmium (Os) concentrations in $\mathrm{Py}_{2}$ range between 4087 and 4541, and 5.09 and $6.20 \mathrm{ppt}$, respectively. The ${ }^{187} \mathrm{Re} /{ }^{188} \mathrm{Os}$ and ${ }^{187} \mathrm{Os} /{ }^{188} \mathrm{Os}$ ratios of $\mathrm{Py}_{2}$ range between 11,203 and 31,074, and 19.04 and 52.36, respectively. Five samples yielded an isochron age of 99.3 $\pm 7.9 \mathrm{Ma}(\mathrm{MSWD}=3.2)$ and $\mathrm{I}_{\mathrm{Os}}$ of $0.6 \pm 2.1$; however, the MSWD is indicative of a relatively large degree of scatter in the data. The results indicate a 0.02 probability of the data fitting the criteria for a model 3 isochron calculated using the ISOPLOT software (Figure 7B), which may be a result of Os loss. Excluding sample J18-4 from the calculation yielded a more precise individual model $3 \mathrm{Re}-$ Os isochron age of $102.0 \pm 3.4 \mathrm{Ma}$ $\left(2 \mathrm{SE} ; \mathrm{MSWD}=0.2 ; \mathrm{I}_{\mathrm{Os}}=0.04 \pm 0.82 ;\right.$ Figure 7D).

The $\mathrm{Py}_{3}$ crystals yielded Re and Os concentrations of 1185-1735 and 2.94-3.20 ppt, respectively, corresponding to ${ }^{187} \mathrm{Re} /{ }^{188} \mathrm{Os}$ ratios of $3957-6443$ and ${ }^{187} \mathrm{Os} /{ }^{188} \mathrm{Os}$ ratios of $6.47-11.39$. Py3 yielded an individual model $3 \mathrm{Re}-\mathrm{Os}$ isochron age of $100.9 \pm 3.1 \mathrm{Ma}\left(2 \mathrm{SE} ; \mathrm{MSWD}=0.019 ; \mathrm{I}_{\mathrm{Os}}=0.54 \pm 0.25\right.$; Figure 7C).

\section{Discussion}

\subsection{Timing of Metallogenesis}

To establish the ore genesis of the Jinchang Deposit, it is necessary to obtain precise geochronological data. Previous geochronological studies established that the Jinchang gold deposit formed during the Cretaceous (Table 2). ${ }^{40} \mathrm{Ar} /{ }^{39} \mathrm{Ar}$ geochronology of quartz from quartz-pyrite veins in orebody $\mathrm{J}-1$ yielded an age of $122.53 \pm 0.88 \mathrm{Ma}$ [10] and an ${ }^{40} \mathrm{Ar} /{ }^{39} \mathrm{Ar}$ plateau age of $122 \mathrm{Ma}$ [6]. Quartz from quartz-pyrite veins in orebody XII yielded an ${ }^{40} \mathrm{Ar} /{ }^{39} \mathrm{Ar}$ isochron age of $119 \pm 5 \mathrm{Ma}$ [11]. Sphalerite from orebody J-9 yielded an ${ }^{40} \mathrm{Ar} /{ }^{39} \mathrm{Ar}$ isochron age of $129 \pm 0.8 \mathrm{Ma}$ [11]. The specific age of mineralization, however, remains unclear. This is firstly due to the fact that quartz and sphalerite are not Au-bearing minerals within the Jinchang Deposit, so the analyses of these minerals define the age of alteration rather than gold mineralization. Secondly, the Jinchang Deposit records evidence of multiple phases of hydrothermal activity, adding further complexity. Even monomineralic quartz samples may contain inclusions of K-feldspar and sericite which, due to their relatively high $\mathrm{K}$ concentrations, may influence the ${ }^{40} \mathrm{Ar} /{ }^{39} \mathrm{Ar}$ results. The relatively low precision of the ${ }^{40} \mathrm{Ar} /{ }^{39} \mathrm{Ar}$ fast neutron activation method means that a spread of ages may be observed between the actual ages of different hydrothermal events, further limiting our ability to constrain the nature of the evolving system [40].

The Re-Os radiogenic system in pyrite can be used as a high-precision geochronometer. This dating method has the advantage of an isotopic closure temperature of $>500{ }^{\circ} \mathrm{C}$, meaning that the results are not easily disturbed by subsequent metamorphism or deformation and therefore are likely to record the timing of primary crystallization [26,41-43]. Since pyrite is the dominant host of gold in the Jinchang Deposit, the age of pyrite formation will likely record the age of gold mineralization.

Five Re-Os isotopic analyses of pyrite reported by Zhang et al. [44] yielded an isochron age of $114 \pm 22 \mathrm{Ma}$; however, the uncertainty on the age is large, probably owing to two factors. First, it is unclear which of the mineralization stages the analyzed pyrite relates to. Pyrite from different ore veins and mineralization stages were analyzed together, resulting in a low degree of confidence in the isochron age and a large age uncertainty [45]. Second, impure separates may yield Re-Os mixed ages of both the pyrite and other material, rather than solely the age of the pyrite [26].

In the present study, three types of pyrite $\left(\mathrm{Py}_{1}, \mathrm{Py}_{2}\right.$, and $\left.\mathrm{Py}_{3}\right)$, reflecting three styles of mineralization, were analyzed. Each stage yields sufficient representative pyrite samples to enable a robust interpretation of the age data. $\mathrm{Py}_{1}, \mathrm{Py}_{2}$, and $\mathrm{Py}_{3}$ yield similar metallogenic ages that are sequentially younger from $\mathrm{Py}_{1}$ to $\mathrm{Py}_{3}$, indicating that the ages are representative and accurate.

Sericite from altered granite in drill holes ZK14 and ZK04 in the No. 18 orebody yields a Rb-Sr age of $107 \pm 5 \mathrm{Ma}$. Together, the sericite and pyrite yield a Rb-Sr age of $104 \pm 6 \mathrm{Ma}$ [19]. This alteration is considered to reflect the initial stage of mineralization in the deposit. The age of gold mineralization should therefore be slightly younger than these ages. The age of gold mineralization is consistent with the Re-Os pyrite age (105.6-97.8 Ma) obtained in this study. A sample of granodiorite was collected 
from a depth of $380 \mathrm{~m}$ in drill hole ZK1001 and yielded a ${ }^{206} \mathrm{~Pb} /{ }^{238} \mathrm{U}$ age of $106.8 \pm 2.0 \mathrm{Ma}$ [21], which is broadly similar to the age of ore formation. Crystallization of a large intrusion and the main stage of mineralization in the development of a gold deposit may occur over several million years [46]. Similarities in the timing of granodiorite emplacement and mineralization within the Jinchang Deposit suggest that the former is the likely source and driver of the latter. The occurrence of granodiorite at depth suggests that mineralization may also extend to deeper structural levels.

Table 2. Isotopic ages of rocks and minerals from the Jinchang gold deposit.

\begin{tabular}{cccc}
\hline Test object & Method & Age & Reference \\
\hline Diorite & $\mathrm{U}-\mathrm{Pb}$ & $209 \pm 1.4 \mathrm{Ma}$ & {$[23]$} \\
Granite & $\mathrm{U}-\mathrm{Pb}$ & $203.62 \pm 0.86 \mathrm{Ma}$ & {$[20]$} \\
Granite & $\mathrm{U}-\mathrm{Pb}$ & $202.1 \pm 3.0 \mathrm{Ma}$ & {$[22]$} \\
Granite & $\mathrm{U}-\mathrm{Pb}$ & $201 \pm 3 \mathrm{Ma}$ & {$[19]$} \\
Granite & $\mathrm{U}-\mathrm{Pb}$ & $184.69 \pm 0.98 \mathrm{Ma}$ & {$[20]$} \\
Dioritic porphyrite & $\mathrm{U}-\mathrm{Pb}$ & $118.4 \pm 1.6 \mathrm{Ma}$ & {$[9]$} \\
Dioritic porphyrite & $\mathrm{U}-\mathrm{Pb}$ & $116 \pm 2 \mathrm{Ma}$ & {$[23]$} \\
Dioritic porphyrite & $\mathrm{U}-\mathrm{Pb}$ & $115.7 \pm 2.0 \mathrm{Ma}$ & {$[9]$} \\
Dioritic porphyrite & $\mathrm{U}-\mathrm{Pb}$ & $111.5 \pm 1.2$ & {$[22]$} \\
Granite porphyry & $\mathrm{U}-\mathrm{Pb}$ & $113.5 \pm 3.6 \mathrm{Ma}$ & {$[24]$} \\
Granite porphyry & $\mathrm{U}-\mathrm{Pb}$ & $112.62 \pm 0.85 \mathrm{Ma}$ & {$[23]$} \\
Granite porphyry & $\mathrm{U}-\mathrm{Pb}$ & $110 \pm 3 \mathrm{Ma}$ & {$[19]$} \\
Granodiorite & $\mathrm{U}-\mathrm{Pb}$ & $106.8 \pm 2.0 \mathrm{Ma}$ & {$[21]$} \\
Quartz-pyrite veins in the J-1 orebody & $40 \mathrm{Ar} /{ }^{39} \mathrm{Ar}$ & $122.53 \pm 0.88 \mathrm{Ma}$ & {$[10]$} \\
Quartz-pyrite veins in the J-2 orebody & $40 \mathrm{Ar} /{ }^{39} \mathrm{Ar}$ plateau & $122 \mathrm{Ma}$ & {$[6]$} \\
Quartz from quartz-pyrite veins of orebody $\mathrm{XII}$ & $40 \mathrm{Ar} / 39 \mathrm{Ar}$ & $119 \pm 5 \mathrm{Ma}$ & {$[11]$} \\
Sericite from altered granite & $\mathrm{Rb}-\mathrm{Sr}$ & $107 \pm 5 \mathrm{Ma}$ & {$[19]$} \\
Sericite and pyrite from altered granite & $\mathrm{Rb}-\mathrm{Sr}$ & $104 \pm 6 \mathrm{Ma}$ & {$[19]$} \\
Sphalerite from J-9 orebody & $40 \mathrm{Ar} / 39 \mathrm{Ar}$ & $129 \pm 0.8 \mathrm{Ma}$ & {$[11]$} \\
Pyrite from J1 orebody & $\mathrm{Re}-\mathrm{Os}$ & $114 \pm 22 \mathrm{Ma}$ & {$[44]$} \\
Py1 & $\mathrm{Re}-\mathrm{Os}$ & $102.9 \pm 2.7 \mathrm{Ma}$ & This study \\
Py2 & $\mathrm{Re}-\mathrm{Os}$ & $102.0 \pm 3.4 \mathrm{Ma}$ & This study \\
Py3 & $\mathrm{Re}-\mathrm{Os}$ & $100.9 \pm 3.1 \mathrm{Ma}$ & This study \\
\hline
\end{tabular}

\subsection{Re-Os Isotopic Compositions and Implications for the Ore Source}

In addition to constraining the age of ore formation, the Re-Os isotopic system can be used to identify the source of the ore-forming material $[3,26]$. Excluding negative values that are inferred to be erroneous or indicative of systematic disturbance, the $\mathrm{I}_{\mathrm{O}}$ values derived from Re-Os pyrite isochrons in this study range from 0.04 to 0.60 (Figure 7). The $\mathrm{I}_{\mathrm{Os}}$ values calculated for individual samples range from 0.14 to 0.54 (Table 1), assuming that $\mathrm{Py}_{1}, \mathrm{Py}_{2}$, and $\mathrm{Py}_{3}$ formed at 102.9, 102.0, and 100.9 Ma, respectively In both instances, the $\mathrm{I}_{\mathrm{Os}}$ values are lower than the upper crustal ${ }^{187} \mathrm{Os} /{ }^{188}$ Os average value of 1.9256 [47]. The $\mathrm{I}_{\mathrm{Os}}$ values lie between the ${ }^{187} \mathrm{Os} /{ }^{188}$ Os values of chondrite $(0.1263)$, which is representative of the mantle composition at $102 \mathrm{Ma}$, and those of the lower crust (0.64-0.96) [48]. These observations suggest that the ore-forming materials in this deposit were derived from a mixed crust-mantle source. In the Re-Os versus common Os diagram (Figure 8; after Lambert et al. [1]), the compositions of the auriferous pyrites are approximately consistent with those of mantle melts and the lower crust, suggesting that the ore-forming materials were derived from a mixed crust-mantle source, with the largest contribution being from the lower crust. 


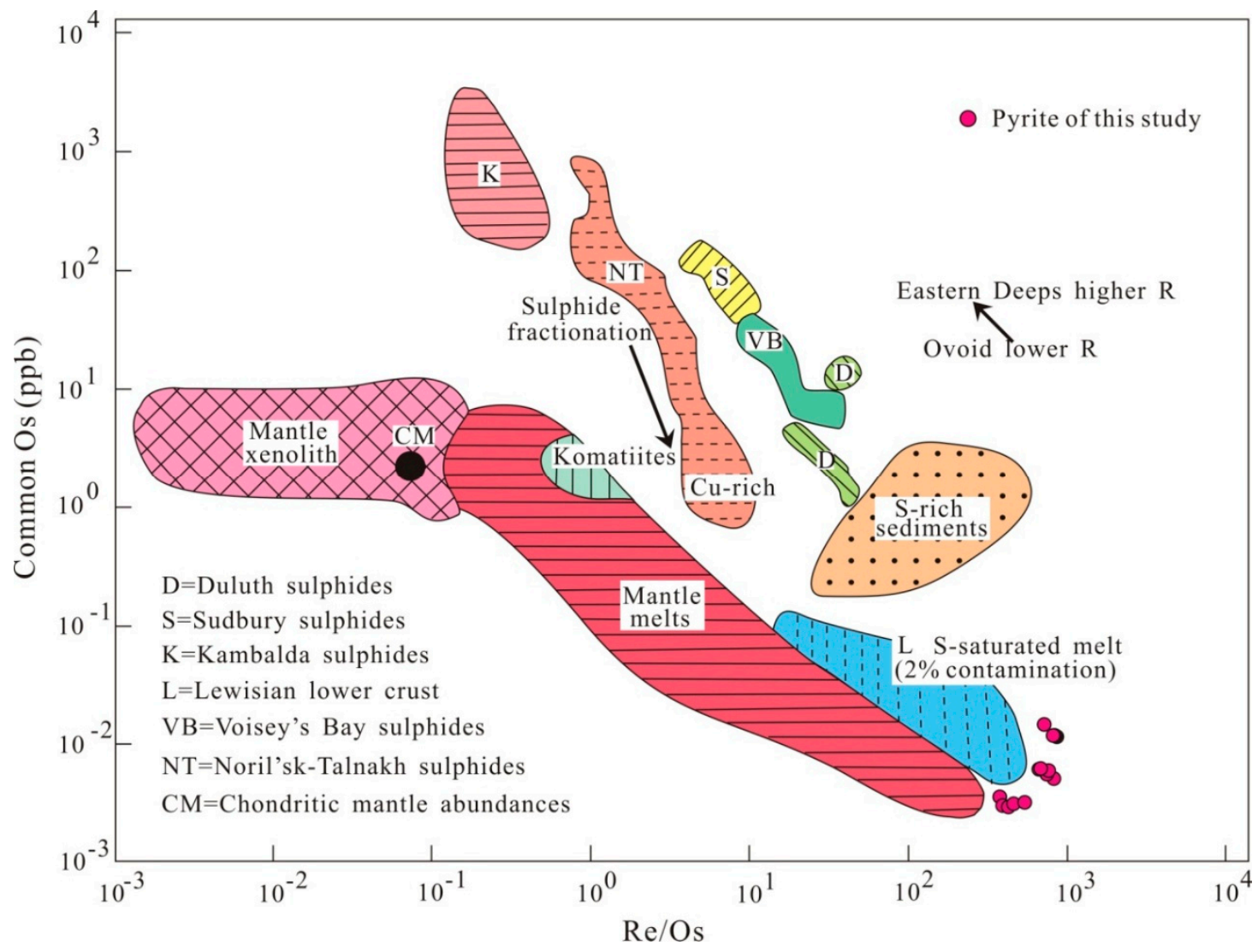

Figure 8. Re/Os versus common Os diagram for auriferous pyrite from the Jinchang Deposit (modified after Lambert et al. [1]).

\subsection{Genesis and Metallogenic Setting of the Jinchang Deposit}

The study area records evidence for collision, deformation, and extension associated with subduction of the west Pacific Plate during the late and early stages of the Indosinian and Yanshannian orogenies, respectively [15]. During the early stages of collision (210-190 Ma), I-type granites intruded the Yanji-Dongning area as a result of upper crustal melting [13,16,49]. At ca. $140 \mathrm{Ma}$, the tectonic setting changed from compression to extension due to closure of the Pacific Ocean during continent-continent collision [50]. During the Early Cretaceous (130-100 Ma), northeast China was undergoing extension, as indicated by bimodal volcanic rocks in the Xiaoxing'anling-Zhangguangcailing region [51-53] and the widespread development of metamorphic core complexes in the Songliao Basin [54].

The timing of mineralization in the various ore deposits within the Yanbian-Dongning area has been investigated by $\mathrm{Ar}-\mathrm{Ar}, \mathrm{Rb}-\mathrm{Sr}, \mathrm{Re}-\mathrm{Os}$, and $\mathrm{U}-\mathrm{Pb}$ geochronology of quartz and muscovite, sericite, sulfides, and zircon, respectively [18,40,54-56]. These analyses yielded ages between 126 and $95 \mathrm{Ma}$, indicating that an important mineralization event took place at this time in the Yanbian-Dongning area. Previous studies have suggested that the ore deposits formed due to regional-scale lithospheric thinning $[13,15,16,57]$.

In the Jinchang Deposit, granodiorite is extensively altered and mineralized, and yields a $\mathrm{U}-\mathrm{Pb}$ age of $106.8 \pm 2.0 \mathrm{Ma}$ (MSWD $=0.65, n=20$ ) [21]. Re-Os dating of pyrites from the ore body yields ages of 105.6-97.8 Ma (This study), which are interpreted as the timing of ore formation. The ages of diagenesis and metallogenesis are within error of each other, suggesting that mineralization was related to granodiorite emplacement. Upwelling mantle-derived magmas would have provided heat to partially melt the lower crust as well as fluids that extracted metals from the lower crust and facilitated their migration to shallower levels (i.e., toward the upper crust). The Re-Os isotopic analyses of pyrites in this study, and the $\mathrm{S}$ and $\mathrm{Pb}$ isotopic compositions of ores analyzed previously, also suggest that 
the ore-forming components were derived from both crust and mantle sources [19]. The ore-forming fluids are interpreted to have contained abundant volatiles that migrated to the intersections of faults. When the fluid pressure exceeded the pressure of the overlying rocks, cryptoexplosions and thereby breccia pipe mineralization occurred. Vein-disseminated mineralization occurred adjacent to the intrusive body, within the surrounding rock. Magma intrusion caused ring and radial faults to form around the magma dome, creating space for hydrothermal migration, fluid mixing, metal precipitation, and thus fault-controlled vein mineralization.

\section{Conclusions}

1. Re-Os isotopic analyses of auriferous pyrites from the Jinchang Deposit yielded ages of 102.9-100.9 Ma, which are interpreted to reflect the age of gold mineralization.

2. Re-Os isotopic compositions suggest that the ore-forming material was derived from lower crustal and mantle sources.

3. Three types of mineralization were contemporaneous, but occurred at different structural locations. Granodiorite emplacement is considered the most likely cause of mineralization.

Author Contributions: Conceptualization, S.-D.L. and K.-Y.W.; Methodology, J.L.; Software, W.-Y.C.; Validation, K.-Y.W., S.-D.L. and L.X.; Formal Analysis, Z.-G.W.; Investigation, S.-D.L.; Resources, K.-Y.W.; Data Curation, S.-D.L.; Writing-Original Draft Preparation, S.-D.L.; Writing-Review \& Editing, K.-Y.W.; Visualization, S.-D.L.; Supervision, D.-W.P.; Project Administration, L.X.; Funding Acquisition, K.-Y.W.

Funding: This work was supported by China Geological Survey, Chinese Ministry of Science and Technology (2017YFC0601304).

Acknowledgments: We are grateful to the staff of the No. 1 Party of Gold Geology, China People's Armed Force, for field work in the Jinchang Mine. Two anonymous reviewers and editor are thanked for their constructive comments and reviews, which have significantly improved this manuscript.

Conflicts of Interest: The authors declare no conflict of interest.

\section{References}

1. Lambert, D.D.; Foster, J.G.; Frick, L.R. Re-Os isotopic systematics of the Voisey's Bay Ni-Cu-Co magmatic ore system, Labrador, Canada. Lithos 1999, 47, 69-88. [CrossRef]

2. Mao, J.W.; Du, A.D. The $982 \mathrm{Ma}$ Re-Os age of copper-cickel sulfide ores in the Baotan area, Guangxi, and its geological significance. Sci. China Ser. D 2001, 31, 992-998. (In Chinese)

3. Stein, H.J.; Morgan, J.W.; Schersten, A. Re-Os dating of low-level highly radiogenic (LLHR) sulfides: The Harnas gold deposit, southwest Sweden, records continental-scale tectonic events. Econ. Geol. 2000, 95, 1657-1671. [CrossRef]

4. Mathur, R.; Ruiz, J.; Titley, S.; Gibbins, S.; Margotomo, W. Different crustal sources for Au-rich and Au-poor ores of the grasberg Cu-Au porphyry deposit. Earth Planet. Sci. Lett. 2000, 183, 7-14. [CrossRef]

5. Kirk, J.D.; Ruiz, J.; Kesler, S.E.; Simon, A.; Muntean, J.L. Re-Os age of the pueblo Viejo epithermal deposit, Dominican Republic. Econ. Geol. 2014, 109, 503-512. [CrossRef]

6. Jia, G.Z.; Chen, J.R.; Yang, Z.G.; Bian, H.Y.; Wang, Y.Z.; Liang, H.J.; Jin, T.H.; Li, Z.H. Geology and genesis of the superlarge Jinchang gold deposit. Acta Geol. Sin. 2005, 79, 661-670. (In Chinese)

7. Zhang, D.H.; Wang, Y.; Wang, D.; Xu, W.X.; Wang, Y.Z.; Zhang, W.Z. Geochemistry of ore forming fluids and genesis of gold ore bodies in the dome-shaped magmatic body-hosted Jinchang gold deposit, Heilongjiang province. Min. Depos. 2006, 25, 155-158. (In Chinese)

8. Wang, Y.; Xi, B.B.; Zhang, D.H.; Zhang, W.H. Geochemical characteristics of fluid inclusions in Jinchang gold deposit, Heilongjiang Province. Min. Depos. 2007, 26, 184-194. (In Chinese)

9. Zhao, Y.S.; Yang, L.Q.; Chen, Y.F.; Qing, M.; Yan, J.P.; Ge, L.S. Geochemisry and zircon U-Pb geochronology of the diorite porphyry associated with the Jinchang $\mathrm{Cu}-\mathrm{Au}$ deposit, Heilongjiang Province. Acta Petrol. Sin. 2012, 28, 451-467. (In Chinese)

10. Chen, J.R.; Jin, B.Y.; Wang, K.Q.; Wu, Y.H. Research Report on Metallogenic Regulation and Prognosis of Jinchang Gold Deposit, Dongning Country, Heilongjiang Province. 2007. Available online: http://ww 
w.wanfangdata.com.cn/details / detail.do?_type=conference\&id=6314107 (accessed on 22 August 2007). (In Chinese)

11. Qing, M.; Tang, M.G.; Xiao, L.; Zhao, Y.S.; Han, X.J. Automatic Laser Probe ${ }^{40} \mathrm{Ar} /{ }^{39} \mathrm{Ar}$ isochron ages of the quatrz and sphalerite from the Jinchang gold deposit, Dongning County, Heilongjiang Province, and their prospecting implications. Geol. Prospect. 2012, 48, 991-999. (In Chinese)

12. Xiao, W.J.; Santosh, M. The western Central Asian Orogenic Belt: A window to accretionary orogenesis and continental growth. Gondwana Res. 2014, 25, 1429-1444. [CrossRef]

13. Mao, J.W.; Xie, G.Q.; Zhang, Z.H.; Li, X.F.; Wang, Y.T.; Zhang, C.Q.; Li, Y.F. Mesozoic large-scale metallogenic pulses in North China and corresponding geodynamic settings. Acta Petrol. Sin. 2005, 21, 169-188.

14. Xu, W.L.; Wang, F.; Meng, E.; Gao, F.H.; Pei, F.P.; Yu, J.J.; Tang, J. Paleozoic-Early Mesozoic Tectonic Evolution in the Eastern Heilongjiang Province NEChina: Evidence from Igneous Rock Association U-Pb Geochronlolgy of Detrital Zircons. J. Jilin Univ. (Earth Sci. Ed.) 2012, 5, 1378-1389. (In Chinese)

15. Sun, J.G.; Chen, L.; Zhao, J.K.; Men, L.J.; Feng, W.; Chen, D.; Liang, S.N. SHRIMP U-Pb dating of zircons from Late Yanshanian granitic complex in Xiaoxinancha gold-rich copper orefield of Yanbian and its geological implications. Miner. Depos. 2008, 3, 319-328. (In Chinese)

16. Ren, Y.S.; Chen, C.; Zou, X.T.; Zhao, H.L.; Hao, Y.J.; Hou, H.N.; Hu, Z.C.; Jiang, G.H. The age, geological setting, and types of gold deposits in the Yanbian and adjacent areas, NE China. Ore Geol. Rev. 2016, 73, 284-297. [CrossRef]

17. Wu, F.Y.; Sun, D.Y.; Ge, W.C.; Zhang, Y.B.; Grant, M.L.; Wilde, S.A.; Jahn, B.M. Geochronology of the Phanerozoic granitoids in northeastern China. J. Asian Earth Sci. 2011, 41, 1-30. [CrossRef]

18. Sun, J.G.; Zhang, Y.; Xing, S.W.; Zhao, K.Q.; Zhang, Z.J.; Bai, L.A.; Ma, Y.B.; Liu, Y.S. Genetic types, ore-forming age and geodynamic setting of endogenic molybdenum deposits in the eastern edge of Xing-Meng orogenic belt. Acta Petrol. Sin. 2012, 28, 1317-1332. (In Chinese)

19. Zhang, H.F.; Li, S.R.; Santosh, M.; Liu, J.J.; Diwu, C.R.; Zhang, H. Magmatism and metallogeny associated with mantle upwelling: Zircon $\mathrm{U}-\mathrm{Pb}$ and $\mathrm{Lu}-\mathrm{Hf}$ constraints from the gold-mineralized Jinchang granite, NE China. Ore Geol. Rev. 2013, 54, 138-156. [CrossRef]

20. Han, S.J.; Yang, Y.C.; Ye, S.Q.; Khomich, V.G.; Boriskina, N.G.; Wang, X.Y. U-Pb zircon and geochemical constraints on age and genesis of granitoids from the Jinchang Au deposit in Heilongjiang, NE China. Geol. J. 2017. [CrossRef]

21. Wang, Z.G. Mineralization and Metallogenic Prediction of Jinchang Cu-Au Deposit in Dongning, Heilongjiang Province. Ph.D. Thesis, Jilin University, Changchun, China, 2018. (In Chinese)

22. Lu, Y.H.; Zhang, Y.; Lai, Y.; Wang, Y.Z. LA-ICP-MS zircon U-Pb dating of magmatism and mineralization in the Jinchang gold ore-field, Heilongjiang province. Acta Petrol. Sin. 2009, 25, 2902-2912. (In Chinese)

23. Zhao, Y.S. Porphyry Gold System of the Jinchang Camp in the Yanbian-Dongning Metallogenic Belt, NE China. Ph.D. Thesis, China University of Geosciences, Beijing, China, 2013. (In Chinese)

24. Qian, Y.; Sun, F.Y.; Li, B.L.; Chen, J.; Diwu, C.R. Geochemistry and U-Pb geochrony of zircon from granite porphyry of Jinchang gold deposit in Heilongjiang, China and its geological significance. J. Chengdu Univ. Technol. 2012, 39, 362-371. (In Chinese)

25. Chen, J.R.; Li, H.G.; Jin, B.Y.; Wu, Y.H.; Wang, Y.Z.; Yu, W.Q. Geological features and the deep metallogenic forecast of the No. J-1 gold body in the Jinchang gold deposit, Heilongjiang. Gold Geol. 2002, 8, 8-12. (In Chinese)

26. Shirey, S.B.; Walker, R.J. Carius tube digestion for low-blank rhenium-osmium analysis. Anal. Chem. 1995, 67, 2136-2141. [CrossRef]

27. Cohen, A.S.; Waters, F.G. Separation of osmium from geological materials by solvent extraction for analysis by thermal ionization mass spectrometry. Anal. Chim. Acta 1996, 332, 269-275. [CrossRef]

28. Pearson, D.G.; Woodland, S.J. Solvent extraction/anion exchange separation and determination of PGE (Os, $\mathrm{Ir}, \mathrm{Pt}, \mathrm{Pd}, \mathrm{Ru}$ ) and Re-Os isotopes in geological samples by isotope dilution ICP-MS. Chem. Geol. 2000, 165, 57-107. [CrossRef]

29. Roy-Barman, M. Mesure du Rapport ${ }^{187}$ Os $/{ }^{186}$ Os dans les Basaltes et les Péridotites: Contribution à la Systématique ${ }^{187} \mathrm{Re}^{187}$ Os dans le Manteau. Ph.D. Thesis, Université de Paris VII, Paris, France, 1993.

30. Li, J.; Zhao, P.P.; Liu, J.G.; Wang, X.C.; Yang, Y.; Wang, G.Q.; Xu, J.F. Reassessment of Hydrofluoric Acid Desilicification in the Carius Tube Digestion Technique for Re-Os Isotopic Determination in Geological Samples. Geostand. Geoanal. Res. 2015, 39, 17-30. [CrossRef] 
31. Creaser, R.A.; Papanastassiou, D.A.; Wasserburg, G.J. Negative thermal ion mass spectrometry of osmium, rhenium and iridium. Geochim. Cosmochim. Acta 1991, 55, 397-401. [CrossRef]

32. Volkening, J.; Walczyk, T.; Heumann, K.G. Osmium isotope ratio determinations by negative thermal ionization mass spectrometry. Int. J. Mass Spectrom. Ion Process. 1991, 105, 147-159. [CrossRef]

33. Li, J.; Liang, X.R.; Xu, J.F.; Suzuki, K.; Dong, Y.H. Simplified technique for the measurements of Re-Os isotope by multicollector inductively coupled plasma mass spectrometry (MC-ICP-MS). Geochem. J. 2010, 44, 73-80. [CrossRef]

34. Li, J.; Jiang, X.Y.; Xu, J.F.; Zhong, L.F.; Wang, X.C.; Wang, G.Q.; Zhao, P.P. Determination of Platinum-Group Elements and Re-Os Isotopes using ID-ICP-MS and N-TIMS from a Single Digestion after Two-Stage Column Separation. Geostand. Geoanal. Res. 2014, 38, 37-50. [CrossRef]

35. Ishikawa, A.; Senda, R.; Suzuki, K.; Dale, C.W.; Meisel, T. Re-evaluating digestion methods for highly siderophile element and ${ }^{187}$ Os isotope analysis: Evidence from geological reference materials. Chem. Geol. 2014, 384, 27-46. [CrossRef]

36. Li, J.; Wang, X.C.; Xu, J.F.; Xu, Y.G.; Tang, G.J.; Wang, Q. Disequilibrium-induced initial Os isotopic heterogeneity in gram aliquots of single basaltic rock powders: Implications for dating and source tracing. Chem. Geol. 2015, 406, 10-17. [CrossRef]

37. Zhang, J.; Li, J.; Long, X.P.; Sun, S.L.; Yin, L.; Dai, M.N. Rhenium-osmium isotope measurements of geological reference material BIR-1a: Evaluation of homogeneity and implications for method validation and quality control. Geostand. Geoanal. Res. 2017. [CrossRef]

38. Ludwig, K. Isoplot/Ex Version 2.0: A Geochronological Toolkit for Microsoft Excel; Special Publication 1a; Geochronology Center: Berkeley, CA, USA, 1999.

39. Smoliar, M.L.; Walker, R.J.; Morgan, J.W. Re-Os ages of group IA, IIA, IVA and IVB iron meteorites. Science 1996, 271, 1099-1102. [CrossRef]

40. Men, L.J. An Ore-forming Fluid Study on Late Mesozoic Epithermal Au-Cu Deposits in Yanbian-Dongning Area: Implication for the Metallogenic Mechanism. Ph.D. Thesis, Jilin University, Changchun, China, 2011. (In Chinese)

41. Stein, H.J.; Sundblad, K.; Markey, R.J.; Morgan, J.W.; Motuza, G. Re-Os ages for Archean molybdenite and pyrite, Kuittila-Kivisuo, Finland and Proterozoic molybdenite, Kabeliai, Lithuania: Testing the chronometer in a metamorphic and metasomatic setting. Min. Depos. 1998, 33, 329-345. [CrossRef]

42. Brenan, J.M.; Cherniak, D.J.; Rose, L.A. Diffusion of osmium in pyrrhotite pyrite: Implications for closure of the Re-Os isotopic system. Earth Plant. Sci. Lett. 2000, 180, 399-413. [CrossRef]

43. Nozaki, T.; Kato, Y.; Suzuki, K. Re-Os geochronology of the Iimori Besshi-type massive sulfide deposit in the Sanbagawa metamorphic belt, Japan. Geochim. Cosmochim. Acta 2010, 74, 4322-4331. [CrossRef]

44. Zhang, P.; Huang, X.W.; Cui, B.; Wang, B.C.; Yin, Y.F.; Wang, J.R. Re-Os isotopic and trace element compositions of pyrite and origin of the Cretaceous Jinchang porphyry $\mathrm{Cu}-\mathrm{Au}$ deposit, Heilongjiang Province, NE China. J. Asian Earth Sci. 2016, 129, 67-80. [CrossRef]

45. Huang, X.W.; Qi, L.; Wang, Y.C.; Liu, Y.Y. Re-Os dating of magnetite from the Shaquanzi Fe-Cu deposit, Eastern Tianshan, NW China. Sci. China Ser. D 2014, 57, 267-277. [CrossRef]

46. Wei, J.H.; Liu, C.Q.; Zhao, Y.X.; Li, Z.D. Time Span of the Major Ore-forming Stages of the Wulong Gold Deposit, Liaoning. Geol. Rev. 2001, 47, 433-437. (In Chinese)

47. Esser, B.K.; Turekian, K.K. The osmium isotopic composition of the continental crust. Geochim. Cosmochim. Acta 1993, 57, 3093-3104. [CrossRef]

48. Saal, A.E.; Rudnick, R.L.; Ravizza, G.E.; Hart, S.R. Re-Os isotope evidence for the composition, formation and age of the lower continental crust. Nature 1998, 393, 58-61. [CrossRef]

49. Han, S.J.; Sun, J.G.; Bai, L.A.; Xing, S.W.; Chai, P.; Zhang, Y.; Yang, F.; Men, L.J.; Li, Y.X. Geology and ages of porphyry and medium- to high-sulphidation epithermal gold deposits of the continental margin of northeast China. Int. Geol. Rev. 2013, 55, 287-310. [CrossRef]

50. Qi, J.P.; Chen, Y.J.; Franco, P. Geological characteristics and tectonic setting of the epithermal deposits in the Northeast China. J. Miner. Petrol. 2005, 25, 47-59. (In Chinese)

51. Ge, W.C.; Lin, Q.; Sun, D.Y.; Wu, F.Y.; Won, C.K.; Lee, M.W.; Jin, M.S.; Yun, S.H. Geochemical characteristics of the Mesozoic basalts in Da Hinggan Ling: Evidence of the mantle-crust interaction. Acta Petrol. Sin. 1999, 15, 397-407. (In Chinese) 
52. Zhang, W.H.; Qin, J.Y.; Zhang, D.H.; Tian, L.; Wang, L.L.; Wang, Y. Fluid inclusion indicators in prophyry Au deposits: Taking Jinchang gold deposit, Heilongjiang Province as an example. Acta Petrol. Sin. 2008, 24, 2011-2016. (In Chinese) [CrossRef]

53. Xu, W.L.; Pei, F.P.; Wang, F.; Meng, E.; Ji, W.Q.; Yang, D.B.; Wang, W. Spatial-temporal relationships of Mesozoic volcanic rocks in NE China: Constraints on tectonic overprinting and transformations between multiple tectonic systems. J. Asian Earth Sci. 2013, 74, 167-193. [CrossRef]

54. Zhao, Y.J.; Sun, J.G.; Wang, Q.H.; Men, L.J.; Li, Y.X.; Guo, J. ${ }^{40} \mathrm{Ar} /{ }^{39} \mathrm{Ar}$ laser probe dating and discussion on metallogenic epoch of epithermal Au-Cu deposit in Yanbian area of Jilin. Earth Sci. Front. 2010, 17, 156-169. (In Chinese)

55. Li, Z.Z.; Li, S.R.; Zhang, H.F. Wall rock alteration and metallogenic chronology of Jinchang gold deposit in Dongning County, Heilongjiang Province. Min. Depos. 2009, 01, 83-92. (In Chinese)

56. Ren, Y.S.; Ju, N.; Zhao, H.L.; Wang, H.; Hou, K.J.; Liu, S. Geochronology and geochemistry of metallogenetic porphyry bodies from the Nongping Au-Cu deposit in the eastern Yanbian area, NE China: Implications for metallogenic environment. Acta Geol. Sin. (Engl. Ed.) 2012, 86, 619-629.

57. Mao, J.W.; Wang, Z.L. A preliminary study on time limits and geodynamic setting of large-scale metallogeny in East China. Min. Depos. 2000, 19, 289-296. (In Chinese)

(c) 2018 by the authors. Licensee MDPI, Basel, Switzerland. This article is an open access article distributed under the terms and conditions of the Creative Commons Attribution (CC BY) license (http://creativecommons.org/licenses/by/4.0/). 